\title{
BIOLOGICAL DIVERSITY OF INVERTEBRATE FAUNA CIRCULATING IN SOME CUCURBIT-BASED MARKET GARDENING AGROSYSTEMS AT MINKO'O (SOUTH REGION, CAMEROON)
}

\author{
Stephanie Kakam ${ }^{1}$, Gaelle Didi Mokam ${ }^{1,2}$, Desiree-Chantal Alene ${ }^{1}$, Zephirin Tadu ${ }^{1}$, Judicael Fomekong \\ Lontchi $^{1}$, Gertrude-Loveline Tchoudjin ${ }^{1}$, Jacques-Anselme Massussi ${ }^{3}$ and Champlain Djieto-Lordon ${ }^{1 *}$ \\ ${ }^{1}$ Laboratory of Zoology, Faculty of Science, University of Yaoundé I, P.O. Box 812, Yaoundé, Cameroon \\ ${ }^{2}$ Department of Biological Science, Faculty of Science, University of Ngaoundéré, P.O. Box 454, Ngaoundéré, \\ Cameroon \\ ${ }^{3}$ Institute of Agricultural Research for Development (IRAD) P.O. Box 2123 Yaoundé, Cameroon
}

https://doi.org/10.35410/IJAEB.2020.5529

\begin{abstract}
Market gardening, one of the predominant activities in developing countries in general and in Cameroon in particular, is nowadays threatened by pests of several animal taxa. These pests cause important yield losses and impose frequent and anarchical applications of large spectrum pesticides that alter product and environment quality. In the perspective of designing a study program on the ecology of major pests of cultivated cucurbit-based agrosystems, the present study aimed at assessing the biological diversity of the invertebrate circulating in these agrosystem. Data were collected at Minko'o, South Region of Cameroon by visual observations in experimental trap gardens from 2015 to 2017. A total of 412 species of 117 families and 20 orders of Invertebrates were identified from a set of 40,741 individuals. This sample comprise Insecta (13 orders), Diplopoda (two orders) and Arachnida (3 orders) and two orders of Gastropoda. The numerically most important orders were Hymenopterans, Hemipterans, Coleopterans, Orthopterans, and Lepidopterans representing $88.67 \%$ of the total abundance. The numerically dominant species belonged mainly to these orders. In relation with host plant preferences, all these orders, families and species showed variable level of selectivity as comparisons of their distribution among studied plants appeared different from one taxon to another.
\end{abstract}

Keywords: Cucurbitaceae, invertebrate, biological diversity, market gardening, inventory.

\section{INTRODUCTION}

Agriculture is one of the major economic sectors in most developing countries, including Cameroon. Since early 1990's, market gardening is taking an increasing part in this socioeconomic sector in urban and peri-urban areas of these countries as well as in their "gross domestic product" (Nguegang, 2008). It provides fresh vegetables and fruits for an expanding urban population and incomes for the majority of low and medium income African people (Beucher and Bazin, 2012). In Cameroon, market gardening is among the main sources of incomes for countryside dwellers and contributes significantly in the national economy (Kengue 
Vol. 5, No. 04; 2020

ISSN: $2456-8643$

et al., 2008). For instance, Cameroon appears as the major vegetable provider for Central African Countries. In Cameroon, its intensification has drastically increased during the last three decades. It came after the worldwide economic crisis of the late 1980s/early 1990s in various developing countries, related to the decline of traditional cash crops prices on international markets (Nguegang, 2008). Market gardening activities include several plant families among which Solanaceae (Djiéto-Lordon et al., 2014, Heumou et al., 2015, Elono Azang et al., 2016), Malvaceae (Bowombé, 2010) and Cucurbitaceae (Fomekong et al., 2008; Mokam et al., 2014, 2018). Considering the potential of the Cucurbitaceae as source of vegetable protein, fat and calcium for human population, they are essential in the fight against malnutrition in poor rural and peri-urban as well as refugee populations (Fokou et al., 2004). This worldwide plant family comprises about 825 species distributed in 119genus (Dupriez and De Leener, 1987; Jeffrey, 1990). The development and expansion of cucurbit crops are threatened by various constraints (Kumar; 1991, Fomekong et al., 2008; Mokam et al., 2018), resulting in an increase of production costs and thus of product prices on the market (Adégbola and Singbo, 2001).

Phytophagous insects, especially pests, are among the main threat for crops production in tropical Africa; they affect both the vegetative (leaves, stems, buds, roots) and the reproductive organs (flowers, fruits and seeds) of the plants and induce significant crop losses (Adja et al., 2015). This situation is accentuated by poor knowledge of cultural practices in terms of diagnosis of these constraints, and the bioecology of pests on one hand and its consequences the bad choice of the appropriate pesticides on the other. To efficiently address this problem while maintaining high production in quantity and quality, various strategies of integrated pest management, including biological control with the use of auxiliaries (mainly predators, parasitoids or microbial pathogens) and biochemical control (based on plant extract) are heavily encouraged (Lambert, 2010). Moreover, the development of effective integrated crop protection strategies relies on a good knowledge of the diversity, biology and ecology of these pests (Vilardebo, 1979) and their associated natural enemies. Some studies have been conducted on the fauna associated with vegetable in the southern Cameroon. Nevertheless, no study has been carried out on the species composition of invertebrates and their associated natural enemies on leaves, flowers, fruits and stems of domesticated cucurbits. It is in this framework that the present study was carried out in order to complete the former inventories of Invertebrates (pests and natural enemies) of domesticated cucurbits (Mokam et al., 2014). It aimed at (i) assessing invertebrate composition per cucurbit plant species/varieties; (ii) determining the most important taxa at three different level (order, family and species) according to numerical abundance, and to (iii) evaluate their preference in host-plants.

\section{MATERIALS AND METHODS \\ 2.1 Study site}

The study was conducted from November 2015 to June 2017 in the Research Center of Forest and Environment (CEREFEN) $\left(03^{\circ} 06^{\prime} \mathrm{N}, 012^{\circ} 21^{\prime} \mathrm{E}\right.$, altitude $\left.659 \mathrm{~m}\right)$ of the Institute of Agricultural Research for the Development (IRAD) located at Minko'o (Dja-and-Lobo Subdivision), in the South Region of Cameroon.

The prevailing climate at Minko'o is equatorial humid climate with four seasons: a long dry season running from mid-November to March, a short dry season extending from June to July, a 
Vol. 5, No. 04; 2020

ISSN: $2456-8643$

long rainy season from August to November and a small rainy season from March to June (Suchel, 1988). The Landscape of the area was an integral part of the Guineo-Congolese forest (Letouzey, 1968), with floristic components of the evergreen forest.

\subsection{Plant material}

The plant material included 11 varieties of seven cucurbit species commonly cultivated in the southern forest zone of Cameroon. They were: Cucumis sativus Linné commonly called cucumber, Cucumeropsis mannii Naudin (white pistachio), Citrullus lanatus (Thumberg) Mansfeld with two varieties (watermelon and egusi (yellow pistachio), Lagenaria siceraria (Molina) Standley (calabash), Cucurbita maxima Duschene (white-seeded melon), Cucurbita moschata (Duchesne ex lam.), with four varieties of melon: butternet and three local morphotypes codified var.1, var.2 and var.3 and Telfaira occidentalis Hook F. (Fluted squash).

\subsection{Experimental design}

The experimental garden consisted in a $420 \mathrm{~m}^{2}$ plot made up with two blocs of nine plates each. Plates were $11 \mathrm{~m}$ long x $1.5 \mathrm{~m}$ wide, separated by $0.5 \mathrm{~m}$ wide furrows. With the exception of the three varieties of $C$. moschata and of $T$. occidentalis, which were grown each on a single ridge; the seven other species were grown on two ridges each. For $T$. occidentalis, distance between plants was $3 \mathrm{~m}$ while for the four varieties of C. moschata and C. maxima, because of their great capacity of expansion, distance between plants was $3.7 \mathrm{~m}$. By this practice invasion of other species was avoided. For C. sativus and the two varieties of C. lanatus, seeds were sowed on two ridges separated each other by furrows of $1 \mathrm{~m}$ while for $C$. mannii and $L$. siceraria, ridges were separated each other by $2.2 \mathrm{~m}$ furrows.

To prevent fungal and bacterial infestations of plants and fruits due to the contact of fruits and leaves with soil and breakage of stems under the weight of fruits, individual plants of $C$. sativus, T. occidentalis and C. mannii were staked.

\subsection{Sampling method}

Data collecting was done during four successive cropping cycles: (i) from November 2015 to March 2016, (ii) mid-March to August 2016, (iii) September 2016 to January 2017 and (iv) from March to June 2017.

Data collecting was conducted from the rise of the first two true leaves on seedlings until the end of each cropping cycle. This activity consisted of prospecting all organs (leaves, stems, fruits and flowers) of each plant species/variety. Insect net and a mouth aspirator were used to catch a sample of each flying species, while forceps were used to collect immature stage. All samples were taken to the laboratory where immature stages were reared up to imaginal moult, as most of the identification keys are based on adult characters. Adults of each invertebrate species or morphospecies collected were fixed in $70 \%$ ethanol, excepted lepidopterans which were kept dry, for further identifications or conformation on voucher collection.

\subsection{Samples identifications}

Identifications were based on adult morphological characters, observed under a binocular stereomicroscope Leica M80. For this purpose, some identification keys including Delvare and Aberlenc (1989) for insect orders and families Villiers (1948); Villiers (1952); Mestre (1988); Poutouli et al. (2011) were used for insects' genera and species determinations. Dichotomous key of Hölldobler and Wilson (1990); Bolton (1994) and Taylor (2010) were used to identify ants. Field determination guides of Bordat and Goudegnon (1991); Michel and Bournier (1997); 
Vol. 5, No. 04; 2020

ISSN: $2456-8643$

Bordat and Arvanitakis (2004) were used to identify many species known taxa as pest insects. The identifications were later confirmed by comparisons with those of the collection of the Laboratory of Zoology, Faculty of Science, University of Yaoundé I.

\subsection{Data analysis}

After identification, cumulative and relative abundances of invertebrates hosted by each plant species/varieties were computed. For the further analysis, taxa (orders, the families and the species) with $\geq 5 \% ; 5 \%<$ relative abundance $\geq 1 \%$ were considered dominants and less abundant respectively. While those with abundance $<1 \%$, were considered scare during the study.

\section{RESULTS AND DISCUSSION}

\subsection{Biological diversity of invertebrates associated with cucurbits}

During the study, a total of 412 species of invertebrates belonging to two phyla, 20 orders and 117 families of invertebrates was identified from a set of 40,741 individuals collected on the 11 species/varieties of cucurbits studied. They belonged into two phyla. The phylum of Arthropoda was the most speciose (18 orders, 112 families and 406 species) and the most abundant numerically (40197 individuals or 98.66\%) than the phylum of Mollusca with two orders, 5 families and 6 species (544 individuals or 1.34\%). Arthropod comprised Arachnida with 3 orders, 6 families and 6 species; Diplopoda with two orders, two families and two species and Insecta with 13 orders, 104 families and 398 species. This community appeared more diversified Fomekong et al. (2008) who collected on the same area on Cucumeropsis mannii (Cucurbitaceae) at Yaoundé (Cameroon), eight orders and 37 families of insects and from that of Adja et al., (2015) who obtained on Lagenaria siceraria and Citrullus lanatus (Cucurbitaceae), 71 species of insects belonging to 41 families and 10 orders at Yamoussoukro (Côte d'Ivoire). These differences could be due either to the number of host plants (sampling material), to the sampling effort, to the extension of the study period, or to geographical variations of the study sites. This result reveals that, in addition to insects, other classes of arthropods namely Arachnida (represented by Acari), Diplopoda (Spirotreptida, Polydesmida) and even some individual of the phylum Mollusca namely Gastropoda (Caenogastropoda, Stylommatophora) can also feed on different organs of cucurbits, that may in certain circumstances particularly on seedling or during the aggregation phase of their larvae cause serious damages to host plant production.

\subsection{Biological diversity at the level of orders}

Among invertebrates, five orders Insecta dominated the community, each with higher species richness representing $88.67 \%$ of the sample. They included orders Hymenoptera (21 families and 89 species) with 11,381 individuals representing $27.94 \%$ of the total individuals collected, Hemiptera (20 families and 95 species) with 11,293 individuals (27.72 \%), Coleoptera (20 families and 102 species) with 8,299 individuals (20.37\%) and Orthoptera (7 families and 58 species) with 3,646 individuals $(8.95 \%)$ and to a lesser extent Lepidoptera (8 families and 10 species) with 1505 individuals (3.69 \%) (Table1).These observations were also mentioned by Vayssières et al. (2001) on market crops at Réunion Island, by Fomekong et al. (2008) on Cucumeropsis mannii (Cucurbitaceae), and by Chougourou et al., (2012) on Lycopersicon esculentum Mill in common of Djakotomey in Benin. Our results are similar to those of Assi et al., (2018); these authors showed that the main insect orders in cucumber culture were Coleoptera, Diptera, Hemiptera, Hymenoptera and Lepidoptera respectively. These results are 
different from those of Koné et al., (2019) obtained on zucchini in Northern Côte d'Ivoire. According to these authors, the main orders of insects colonizing zucchini plots are Homoptera, Hymenoptera and Diptera. This difference could be explained by the fact that both studies were conducted at different seasons. The climate of Korhogo is characterized by two seasons while ours by four seasons. Besides Koné et al., (2019) has thought that the season has an influence on the entomofauna of Cucurbits. Moreover, five other orders, each less species and less abundant numerically were also observed. They were orders of Aranea, Thysanoptera, Diptera, Polydesmida, and Spirostreptida (Table1).In relation with host plant selection, all these orders showed variable level of selectivity; their distribution among studied plants appeared different from one order to another. 
Table 1. List of the orders of invertebrates collected during the study

\begin{tabular}{|c|c|c|c|c|c|c|c|c|c|c|c|c|}
\hline \multirow{2}{*}{$\begin{array}{c}\text { Orders (species } \\
\text { richness) }\end{array}$} & \multicolumn{11}{|c|}{ Abundance of Invertebrates per Cucurbit species / varieties } & \multirow[t]{2}{*}{ Total } \\
\hline & $\overline{\mathbf{A}}$ & $\mathbf{B}$ & $\mathbf{C}$ & $\mathbf{D}$ & $\mathbf{E}$ & $\mathbf{F}$ & $\mathbf{G}$ & $\mathbf{H}$ & $\mathbf{I}$ & $\mathbf{J}$ & $\mathbf{K}$ & \\
\hline \multicolumn{13}{|c|}{ Arachnida } \\
\hline Acari (3) & $0(0)$ & $0(0)$ & $0(0)$ & $0(0)$ & $0(0)$ & $15(93.75)$ & $0(0)$ & $1(6.25)$ & $0(0)$ & $0(0)$ & $0(0)$ & $16(0.04)$ \\
\hline Aranea(2) & $146(12.64)$ & $10(8.92)$ & $167(14.46)$ & $68(5.89)$ & $79(6.84)$ & $73(6.32)$ & $105(9.09)$ & $87(7.53)$ & $88(7.62)$ & $166(14.37)$ & $73(6.32)$ & $1155(2.83)$ \\
\hline Opilion (1) & $29(93.55)$ & $0(0)$ & $0(0)$ & $0(0)$ & $0(0)$ & $0(0)$ & $0(0)$ & $0(0)$ & $2(6.45)$ & $0(0)$ & $0(0)$ & $31(0.08)$ \\
\hline Polydesmida (1) & $79(13.93)$ & $45(7.94)$ & 68(11.99) & $36(6.35)$ & $31(5.47)$ & $20(3.53)$ & $61(10.76)$ & $9(1.59)$ & $32(5.64)$ & $99(17.46)$ & $87(15.34)$ & $567(1.39)$ \\
\hline Spirostreptida (1) & $102(19.92)$ & $48(9.38)$ & $92(17.96)$ & $34(6.64)$ & $15(2.93)$ & $38(7.42)$ & $27(5.27)$ & $10(1.95)$ & $23(4.49)$ & $63(12.30)$ & $60(11.72)$ & $512(1.26)$ \\
\hline \multicolumn{13}{|c|}{ Insecta } \\
\hline Coleoptera (102) & $933(11.24)$ & $617(7.43)$ & $869(10.47)$ & $446(5.37)$ & $402(4.84)$ & $760(9.16)$ & $880(10.60)$ & $43(5.19)$ & $570(6.87)$ & $2168(26.12)$ & $223(2.69)$ & $\begin{array}{l}8299 \\
(20.37)\end{array}$ \\
\hline Dermaptera (2) & $7(8.64)$ & $1(1.23)$ & $7(8.64)$ & $2(2.47)$ & $12(14.81)$ & $7(8.64)$ & $15(18.52)$ & $4(4.94)$ & $2(30.86)$ & $0(0)$ & $1(1.23)$ & $81(0.2)$ \\
\hline Diptera (31) & $2(0.34)$ & $5(0.85)$ & $7(1.19)$ & $18(3.07)$ & $56(9.56)$ & $131(22.35)$ & $109(18.60)$ & $15(2.56)$ & $59(10.07)$ & $18(3.07)$ & $0(0)$ & $586(1.44)$ \\
\hline Dictyoptera (3) & $25(7.84)$ & $24(7.52)$ & $46(14.42)$ & $8(2.51)$ & $12(3.76)$ & $31(9.72)$ & $6(1.88)$ & $8(2.51)$ & $13(4.08)$ & $114(35.74)$ & $32(10.03)$ & $319(0.78)$ \\
\hline Hemiptera (95) & $944(8.36)$ & $402(3.56)$ & $835(7.39)$ & $2048(18.14)$ & $717(6.35)$ & $852(7.54)$ & $681(6.03)$ & $379(3.36)$ & $597(5.29)$ & $3625(32.10)$ & 213(1.89) & $\begin{array}{l}11293 \\
(27.72)\end{array}$ \\
\hline $\begin{array}{c}\text { Hymenoptera } \\
\text { (89) }\end{array}$ & $1412(12.41)$ & $1020(8.96)$ & $1152(10.12)$ & $718(6.31)$ & $571(5.02)$ & $1271(11.17)$ & $1096(9.63)$ & $828(7.28)$ & $718(6.31)$ & 2051(18.02) & $544(4.78)$ & $\begin{array}{l}11381 \\
(27.94)\end{array}$ \\
\hline Lepidoptera (10) & $82(5.45)$ & $15(1.00)$ & $33(2.19)$ & $75(4.98)$ & $19(1.26)$ & $32(2.13)$ & $29(1.93)$ & $9(0.60)$ & $26(1.73)$ & 1181(78.47) & $4(0.27)$ & 1505 (3.69) \\
\hline Neuroptera (3) & $14(15.38)$ & $5(5.49)$ & $7(7.69)$ & $7(7.69)$ & $8(8.79)$ & $17(18.68)$ & $12(13.19)$ & $0(0)$ & $2(2.20)$ & $19(20.88)$ & $0(0)$ & $91(0.22)$ \\
\hline Plecoptera (1) & $6(6.90)$ & $3(3.45)$ & $18(20.69)$ & $0(0)$ & $5(5.74)$ & $8(9.20)$ & $2(2.30)$ & $0(0)$ & $5(5.75)$ & $17(19.54)$ & $23(26.44)$ & $87(0.21)$ \\
\hline Psocoptera (1) & $0(0)$ & $0(0)$ & $0(0)$ & $0(0)$ & $0(0)$ & $0(0)$ & $0(0)$ & $1(100)$ & $0(0)$ & $0(0)$ & $0(0)$ & $1(0)$ \\
\hline Thysanoptera (2) & $200(32.10)$ & $88(14.13)$ & $1(0.16)$ & $120(19.26)$ & $27(4.33)$ & $26(4.17)$ & $13(2.09)$ & $28(4.49)$ & $17(2.73)$ & $103(16.53)$ & $0(0)$ & $623(1.53)$ \\
\hline \multicolumn{13}{|c|}{ Gastropoda } \\
\hline $\begin{array}{c}\text { Caenogastropoda } \\
\text { (4) }\end{array}$ & $39(11.89)$ & $19(5.79)$ & $51(15.55)$ & $16(4.88)$ & $19(5.79)$ & $48(14.63)$ & $45(13.72)$ & $14(4.27)$ & $18(5.49)$ & $19(5.79)$ & $40(12.20)$ & $328(0.81)$ \\
\hline $\begin{array}{c}\text { Stylommatophora } \\
\text { (2) }\end{array}$ & $29(13.43)$ & $19(8.80)$ & $41(18.98)$ & $42(19.44)$ & $13(6.02)$ & $14(6.48)$ & $14(6.48)$ & $2(0.93)$ & $15(6.94)$ & $17(7.87)$ & $10(4.63)$ & $216(0.53)$ \\
\hline Total & $4561(11.20)$ & 2726(6.69) & $3884(9.53)$ & $3893(9.56)$ & $2242(5.50)$ & $3654(8.97)$ & $3319(8.15)$ & $1954(4.80)$ & $2427(5.96)$ & $10464(25.68)$ & $1617(3.97)$ & $\begin{array}{l}40741 \\
(100.00)\end{array}$ \\
\hline
\end{tabular}

Legend: Figures represent the abundance per plant species/variety in brackets are the relative abundance according to the plant species; A: Citrullus lanatus var. egusi; B: Citrullus lanatus var. watermelon; C: Cucumeropsis mannii; D: Cucumis sativus; E: Cucurbita maxima; F: Cucurbita moschata var..1; G: Cucurbita moschata var.2; H: Cucurbita moschata var.3; I: Cucurbita moschata var. butternet; J: Lagenaria siceraria; K: Telfairao ccidentalis

\subsection{Biological diversity at the level of families for the most abundant orders}

Without consideration of plant species/varieties, among the 117 families of invertebrates identified during the present survey, only five families within Insecta showed relative abundance $\geq 5 \%$ (Table 2 ). Then, the community was dominated by families Formicidae (representing 24.58\% of the total fauna), Chrysomelidae (12.66\%), Aphididae (9.66\%), Miridae (6.27\%) and Aleyrodidae (5.84\%). Moreover 13 families, namely Acrididae (4.10\%), Pyrgomorphidae (3.52\%), Aranea Fm2 (2.66\%), Pterophoridae (2.75\%), Apidae (2.62\%), Nutidulidae (2.13\%), Tenebrionidae (2.08\%), Coccinellidae (2.02\%), Thripidae (1.53\%), Coreidae (1.43\%), Paradoxosomatidae (1.39\%), Odontopygidae $(1.26 \%)$ and Ciccadellidae $(1.25 \%)$ were also numerically important, with relative abundance $\geq 1 \%$ (Table 2). The activity of the species belonging to these families greatly affects the development and the growth of the plant. The main insect families collected during the present study differed to a certain extent from those observed on L. siceraria and C. lanatus by Adja et al., (2015) in Ivory Coast. For instance, the pest community described by these authors included especially the families of Chrysomelidae, Coccinellidae and Meloidae, whose larvae and adults are mainly leaf eaters.

According to the selectivity of these invertebrate opposite host plant species/varieties, Formicidae, Chrysomelidae and Miridae showed similar distribution model within plant species with the highest abundance on $L$. siceraria and the lowest on T. occidentalis while Aphididae was the most abundant on L. siceraria (50.34\%) and on Cucumis sativus (35.36\%). Occurrence of invertebrate families varied according to cucurbit species/varieties; so, the family Aphididae was not encountered on Cucurbita moschata var.2. The family of Aleyrodidae was not encountered on T. occidentalis and on Citrullus lanatus var. watermelon, meanwhile, this family 
appeared mostly abundant on Cucurbita maxima (17.23\%) (Table 2). Specificity was shown between individuals from the family Pterophoridae and the plant species L. siceraria, as its abundances were higher only on this plant species (98.84\%). The same trend was observed among the less frequent families (relative abundance below 5\%) (Table 2).

Table 2. List of the main families of invertebrates (relative abundance above 1\%) collected during the study

\begin{tabular}{|c|c|c|c|c|c|c|c|c|c|c|c|c|}
\hline \multirow[b]{2}{*}{ Families } & \multicolumn{11}{|c|}{ Abundance of Invertebrates per Cucurbit species / varieties } & \multirow{2}{*}{ total } \\
\hline & $\mathbf{A}$ & B & $\mathbf{C}$ & D & $\mathbf{E}$ & $\mathbf{F}$ & $\mathbf{G}$ & $\mathbf{H}$ & I & $\mathbf{J}$ & $\mathbf{K}$ & \\
\hline Acrididae & 206(12.32) & $134(8.01)$ & $214(12.80)$ & $159(9.51)$ & $97(5.80)$ & $145(8.67)$ & $115(6.88)$ & $56(3.35)$ & $72(4.31)$ & $321(19.20)$ & $153(9.15)$ & $1672(4.10)$ \\
\hline Aleyrodidae & $355(14.92)$ & $0(0)$ & $166(6.97)$ & $286(12.02)$ & $410(17.23)$ & 295(12.39) & $255(10.71)$ & $153(6.43)$ & $210(8.82)$ & $250(10.50)$ & $0(0)$ & $2380(5.84)$ \\
\hline Aphididae & $110(2.79)$ & $171(4.34)$ & $85(2.16)$ & 1392(35.36) & $12(0.30)$ & 47(1.19) & $0(0)$ & $35(0.89)$ & $102(2.59)$ & 1982(50.34) & $10(0.03)$ & 3937(9.66) \\
\hline Apidae & 116(10.86) & $148(13.86)$ & $68(6.37)$ & 143(13.39) & $98(9.18)$ & $112(10.49)$ & $146(13.67)$ & $54(5.06)$ & $78(7.30)$ & $105(9.81)$ & $0(0)$ & $1068(2.62)$ \\
\hline $\mathrm{Fm}_{.2}$ & $139(12.82)$ & $103(9.50)$ & $153(14.11)$ & $68(6.27)$ & $68(6.27)$ & $64(5.90)$ & $88(8.12)$ & $77(7.10)$ & $88(8.12)$ & $164(15.13)$ & $72(6.64)$ & $5156(12.66)$ \\
\hline Chrysomelidae & $808(15.67)$ & 497(9.64) & $633(12.28)$ & $237(4.60)$ & $224(4.34)$ & 499(9.68) & 497(9.64) & $282(5.47)$ & $230(4.46)$ & $1175(22.79)$ & $74(1.44)$ & $509(1.25)$ \\
\hline Ciccadellidae & $71(13.95)$ & $40(7.86)$ & $60(11.79)$ & $73(14.34)$ & $33(6.48)$ & $21(4.13)$ & $15(2.95)$ & $7(1.38)$ & $15(2.95)$ & $151(29.67)$ & $23(4.52)$ & $829(2.03)$ \\
\hline Coccinellidae & $2(0.24)$ & $10(1.21)$ & $17(2.05)$ & $125(15.08)$ & $8(0.97)$ & $48(5.79)$ & $60(7.24)$ & $12(1.45)$ & $144(17.37)$ & $403(48.61)$ & $0(0)$ & $582(1.43)$ \\
\hline Coreidae & $85(14.61)$ & $17(2.92)$ & $63(10.82)$ & $48(8.25)$ & $23(3.95)$ & $91(15.64)$ & $126(21.65)$ & $27(4.64)$ & $29(4.98)$ & $73(12.54)$ & $0(0)$ & $1084(2.66)$ \\
\hline Formicidae & $1275(12.73)$ & $860(8.59)$ & 1071(10.69) & $568(5.67)$ & $469(4.68)$ & $1124(11.22)$ & $929(9.28)$ & 771(7.70) & $624(6.23)$ & 1804(18.01) & $521(5.20)$ & $10016(24.58)$ \\
\hline Miridae & $171(6.69)$ & $100(3.92)$ & $234(9.16)$ & $156(6.11)$ & 202(7.91) & $275(10.77)$ & $178(6.97)$ & $116(4.54)$ & $184(7.20)$ & $931(36.45)$ & $7(0.27)$ & $2554(6.27)$ \\
\hline Nutidulidae & $1(0.12)$ & $1(0.12)$ & $0(0)$ & $2(0.23)$ & $103(11.87)$ & $108(12.44)$ & $94(10.83)$ & $35(4.03)$ & $77(8.87)$ & $447(51.50)$ & $0(0)$ & $868(2.13)$ \\
\hline Odontopygidae & 102(19.92) & $48(9.38)$ & $92(17.97)$ & $34(6.64)$ & $15(2.93)$ & $38(7.42)$ & $27(5.27)$ & $10(1.95)$ & $23(4.49)$ & $63(12.30)$ & $60(11.72)$ & $512(1.26)$ \\
\hline $\begin{array}{l}\text { Paradoxo } \\
\text { somatidae }\end{array}$ & 79(13.93) & $45(7.94)$ & 68(11.99) & $36(6.35)$ & $31(5.47)$ & $20(3.53)$ & $61(10.76)$ & $9(1.59)$ & $32(5.64)$ & $99(17.46)$ & $87(15.34)$ & $567(1.39)$ \\
\hline Pterophoridae & $0(0)$ & $0(0)$ & $8(0.71)$ & $0(0)$ & $0(0)$ & $1(0.09)$ & $0(0)$ & $2(0.18)$ & $2(0.18)$ & 1106(98.84) & $0(0)$ & $\begin{array}{l}1119 \\
(2.75)\end{array}$ \\
\hline Pyrgomorphidae & $250(17.43)$ & $132(9.21)$ & $211(14.71)$ & $79(5.51)$ & $122(8.51)$ & $120(8.37)$ & $71(4.95)$ & $47(3.28)$ & $99(6.90)$ & 215(14.99) & $88(6.14)$ & $\begin{array}{l}1434 \\
(3.52)\end{array}$ \\
\hline Tenebrionidae & $93(10.95)$ & $61(7.18)$ & $129(15.19)$ & $64(7.54)$ & $43(5.06)$ & $51(6.01)$ & $69(8.13)$ & $60(7.07)$ & $54(6.36)$ & $106(12.49)$ & $119(14.02)$ & $849(2.08)$ \\
\hline Thripidae & $200(32.10)$ & $88(14.13)$ & $1(0.16)$ & $120(19.26)$ & $27(4.33)$ & $26(4.17)$ & $13(2.09)$ & $28(4.49)$ & $17(2.73)$ & $103(16.53)$ & $0(0)$ & $623(1.53)$ \\
\hline Others families & 498(10.00) & $271(5.44)$ & $611(12.26)$ & $303(6.08)$ & $257(5.16)$ & $569(11.42)$ & $575(11.54)$ & $173(3.47)$ & $347(6.97)$ & $966(19.40)$ & $412(8.27)$ & $\begin{array}{r}4982 \\
(12.23)\end{array}$ \\
\hline Total & $4561(11.20)$ & $2726(6.69)$ & $3884(9.53)$ & 3893(9.56) & $2242(5.50)$ & $3654(8.97)$ & $3319(8.15)$ & 1954(4.80) & $2427(5.96)$ & $10464(25.68)$ & 1617(3.97) & $\begin{array}{l}40741 \\
(100)\end{array}$ \\
\hline
\end{tabular}

Legend: Figures represent the abundance per plant species/variety in brackets are the relative abundance according to the plant species; A: Citrullus lanatus var. egusi; B: Citrullus lanatus var. watermelon; C: Cucumeropsis mannii; D: Cucumis sativus; E: Cucurbita maxima; F: Cucurbita moschata var.1; G: Cucurbita moschata var.2; H: Cucurbita moschata var.3; I: moschata var. butternet; J: Lagenaria siceraria; K:Telfaira occidentalis.

\subsection{Biological diversity at the level of species}

The order Hemiptera was the most speciose, with 95 species belonging to 20 families. Among them Aphis gossypii Glover, 1877 (Aphididae) with $9.66 \%$ of the total fauna, followed by Bemisia tabaci (Gennadius) (Aleyrodidae) (5.84\%), Halticus sp. (Miridae) (4.45\%), Leptoglossus australis Fabricius, 1775 (Coreidae) (1.38\%) and Nesidiocoris sp. (Miridae) (1.60\%) were the most abundant.

According to cucurbit species/varieties, a relative selectivity in host plants was observed as A. gossypii was most abundant on $L$. siceraria $(50.38 \%)$ of the individuals followed by C. sativus (35.37\%), while B. tabaci was most abundant on C. maxima (17.23\%) and C. lanatus var. egusi (14.92\%) (Table 3). Similar trend was observed for the other species (Table 3).

The order of Hymenoptera was represented by 89 species belonging to 21 families. The ants (Formicidae) Pheidole megacepahala Fabricius, 1793 (7.79\%), Myrmicaria opaciventris Emery, 1893 (6.32\%), Camponotus flavomarginatus Mayr, 1862 (2.50\%), Lepisiota guineensis Mayr, 1902 (1.24\%), Odontomacus troglodytes André, 1887 (1.21\%), the bee Apis mellifera Linné, 1758(1.35\%) and the unidentified bee species Gen.142 sp. (1.21\%) appeared the most abundant. Concerning host plant selectivity, P. megacephala 
M. opaciventris were more frequent on $L$. siceraria while $C$. flavomarginatus was more represented on $C$. lanatus var. egusi. Similar trend was observed on the other species (Table 3).

The order of Coleoptera was represented by 102 species belonging to 21 families. The family of Chrysomelidae which was represented by Lamprocopa occidentalis Weise, 1895 (4.95\%), Leptaulaca fissicollis Thomson, 1858 (3.66\%) and Monolepta intermedia Ritsema, 1875 (1.16\%); the family of Nutidulidae with Epuraea sp. (2.11\%), Henosepilachna reticulata Olivier, 1791 (Coccinellidae) (1.82\%), Lagria villosa Fabricius, 1783 (Tenebrionidae) (1.41\%) were the most abundant. In relation to host plant selectivity, the same trend was observed with preference for $L$. siceraria for almost all species with exception of $L$. villosa, most abundant on C. mannii (Table 3).

The order Orthoptera was represented by 58 species belonging to seven families. Among them, two species, Atractomorpha acutipennis Bolivar, 1884 (Pyrgomorphidae) (1.80\%) and Oxycatantops spissus Walker, 1870 (Acrididae) (2.42\%) were numerically dominant. (Table 3). Concerning the selectivity in host plant, these two species were most frequent respectively on $C$. lanatus var. egusi for Atractomorpha acutipennis and on L. siceraria for $O$. spissus (Table 3).

The Lepidoptera contained 10 species belonging to eight families but a single specie most abundant, Sphenarches anisodactylus Walker, 1864. This species belonging to the family Pterophoridae was recorded with a relative abundance of $2.75 \%$. This species was mostly abundant on L. siceraria $(98.84 \%)$ (Table 3).

Four orders, although relatively represented, contained only species with weak abundances. These included Thysanoptera, Aranea, Polydesmida and Spirostreptida. The Thysanoptera, in the majority represented by Thrips sp., occurred with a relative abundance of $1.50 \%$. The Aranea were represented by several unidentified species belonging to the genus codified Aranea-Gen.3 sp..The Polydesmida were represented by the species Habrodesmus falx Cook, 1896 (family Paradoxosomatidae) while the Spirostreptida were represented by the species Trichochalopuncus sp. (family Odontopygidae) (Table 3). At a lesser extent, these species also were unequally distributed among studied plant species.

To certain extent, these observations differed from those of Adja et al., (2015) who reported that Lamprocopa occidentalis, Aulacophora foveicolis, Aulacophora africana, Asbecesta cyanipennis, Ootheca mutabilis, Lilioceris livida, Henosepilachna elaterii, Henosepilachna reticulate and Mylabrisholosericea (Coleoptera) were the main pests on L. siceraria and C. lanatus (Cucurbitaceae). This finding is also different from that of Vinutha et al., (2017) who, in India showed that Aulacophora foveicollis Lucas (Chrysomelidae), Thrips tabaci Lindeman (Thripidae), Eurybrachys tomentosa (Fabricius) (Eurybrachidae), Liriomyza trifolli Burgess (Agromyzidae), Bactocera cucurbitae Coq. (Tephritidae), Spilostethus pandurus (Scopoli) (Lygaeidae), Spilostethus hospes (Fabricius) and Coccinella transversalis (Fabricius) (Coccinellidae) were commonly found on oriental pickling melon, Cucumis melo var. conomon.

The majority of species observed during this study were represented in a fair manner on cucurbit species although some of them were highly abundant on some plant species. This can be explained by the fact that the species of the fauna observed have the same capacity for colonization of the species of cucurbits. However, some species showed a great preference for some cucurbit species.

Table 3. List of the main species of invertebrates (relative abundance above $1 \%$ ) collected during the study

\begin{tabular}{|c|c|c|c|c|c|c|c|c|c|c|c|c|}
\hline \multirow[b]{2}{*}{ Species } & \multicolumn{11}{|c|}{ Cucurbits species and varieties studied } & \multirow[b]{2}{*}{ Total } \\
\hline & A & $\mathrm{B}$ & $\mathrm{C}$ & $\mathrm{D}$ & $\mathrm{E}$ & $\mathrm{F}$ & $\mathrm{G}$ & $\mathrm{H}$ & $\mathrm{I}$ & $\mathrm{J}$ & $\mathrm{K}$ & \\
\hline \multicolumn{13}{|c|}{ Aranea } \\
\hline Gen.3sp. & $139(12.82)$ & $103(9.5)$ & $153(14.11)$ & $68(6.27)$ & $68(6.27)$ & $88(8.12)$ & $64(5.9)$ & $88(8.12)$ & $77(7.1)$ & $164(15.13)$ & $72(6.64)$ & $1084(2.66)$ \\
\hline \multicolumn{13}{|c|}{ Coleoptera } \\
\hline Epuraea sp. & $1(0.12)$ & $1(0.12)$ & $0(0)$ & $0(0)$ & 103(11.96) & $73(8.48)$ & $108(12.54)$ & $94(10.92)$ & $35(4.07)$ & $446(51.8)$ & $0(0)$ & $861(2.11)$ \\
\hline $\begin{array}{l}\text { Henosepilachna } \\
\text { Reticulate }\end{array}$ & $0(0)$ & $1(0.13)$ & $3(0.4)$ & $98(13.23)$ & $5(0.67)$ & $142(19.16)$ & $44(5.94)$ & $53(7.15)$ & $10(1.35)$ & $385(51.96)$ & $0(0)$ & $741(1.82)$ \\
\hline $\begin{array}{l}\text { Lagria } \\
\text { Villosa }\end{array}$ & $55(9.6)$ & $45(7.85)$ & $90(15.71)$ & $42(7.33)$ & $24(4.19)$ & $43(7.5)$ & $40(6.98)$ & $47(8.2)$ & $45(7.85)$ & $69(12.04)$ & $73(12.74)$ & $573(1.41)$ \\
\hline $\begin{array}{l}\text { Lamprocopa } \\
\text { Occidentalis }\end{array}$ & $267(13.23)$ & $140(6.94)$ & $96(4.76)$ & $102(5.05)$ & $152(7.53)$ & $125(6.19)$ & $245(12.14)$ & $322(15.96)$ & $90(4.46)$ & $453(22.45)$ & $26(1.29)$ & 2018(4.95) \\
\hline $\begin{array}{l}\text { Leptaulaca } \\
\text { Fissicollis }\end{array}$ & 291(19.52) & $210(14.08)$ & $234(15.69)$ & $60(4.02)$ & $43(2.88)$ & $57(3.82)$ & $80(5.37)$ & $76(5.1)$ & $85(5.7)$ & $344(23.07)$ & 11(0.74) & 1491(3.66) \\
\hline $\begin{array}{l}\text { Monolepta } \\
\text { Intermedia }\end{array}$ & $99(20.97)$ & $56(11.86)$ & 88(18.64) & 16(3.39) & $8(1.69)$ & $13(2.75)$ & $40(8.47)$ & $12(2.54)$ & $36(7.63)$ & $99(20.97)$ & $5(1.06)$ & $472(1.16)$ \\
\hline \multicolumn{13}{|c|}{ Hemiptera } \\
\hline Aphis gossypii & $110(2.79)$ & $171(4.34)$ & $85(2.16)$ & 1392(35.37) & $12(0.3)$ & $102(2.59)$ & 47(1.19) & $0(0)$ & $35(0.89)$ & 1982(50.36) & $0(0)$ & $3936(9.66)$ \\
\hline Bemisia tabaci & $355(14.92)$ & $(0)$ & $166(6.97)$ & $286(12.02)$ & $410(17.23)$ & $210(8.82)$ & 295(12.39) & $255(10.71)$ & $153(6.43)$ & $250(10.5)$ & $(0)$ & $2380(5.84)$ \\
\hline Halticus sp. & 157(8.66) & $98(5.41)$ & $218(12.03)$ & $151(8.33)$ & 195(10.76) & $169(9.33)$ & 246(13.58) & $168(9.27)$ & $115(6.35)$ & $295(16.28)$ & $0(0)$ & $1812(4.45)$ \\
\hline $\begin{array}{l}\text { Leptoglossus } \\
\text { australis }\end{array}$ & $83(14.72)$ & $16(2.84)$ & $60(10.64)$ & $43(7.62)$ & $23(4.08)$ & $28(4.96)$ & $89(15.78)$ & $125(22.16)$ & $26(4.61)$ & $71(12.59)$ & $0(0)$ & $564(1.38)$ \\
\hline $\begin{array}{l}\text { Nesidiocoris } \\
\text { sp. }\end{array}$ & $12(1.84)$ & $1(0.15)$ & $1(0.15)$ & $0(0)$ & $4(0.61)$ & $0(0)$ & $2(0.31)$ & $0(0)$ & $0(0)$ & $632(96.93)$ & $0(0)$ & $652(1.60)$ \\
\hline \multicolumn{13}{|c|}{ Hymenoptera } \\
\hline Apis mellifera & 108(19.71) & $134(24.45)$ & $65(11.86)$ & $132(24.09)$ & $0(0)$ & $4(0.73)$ & $0(0)$ & $0(0)$ & $0(0)$ & $105(19.16)$ & $0(0)$ & $548(1.35)$ \\
\hline $\begin{array}{l}\text { Camponotus } \\
\text { flavomarginatus }\end{array}$ & $209(20.51)$ & $77(7.56)$ & $100(9.81)$ & 72(7.07) & $29(2.85)$ & $46(4.51)$ & $70(6.87)$ & 106(10.4) & 119(11.68) & $133(13.05)$ & $58(5.69)$ & $1019(2.5)$ \\
\hline Gen. ${ }_{142} \mathrm{sp}$ & $8(1.62)$ & $14(2.84)$ & $3(0.61)$ & $0(0)$ & $98(19.88)$ & $74(15.01)$ & $112(22.72)$ & $146(29.61)$ & $38(7.71)$ & $0(0)$ & $0(0)$ & $493(1.21)$ \\
\hline $\begin{array}{l}\text { Lepisiota } \\
\text { guineensis }\end{array}$ & $143(28.89)$ & $3(0.61)$ & $11(2.22)$ & $48(9.7)$ & $10(2.02)$ & $3(0.61)$ & $109(22.02)$ & $55(11.11)$ & $28(5.66)$ & $42(8.48)$ & 43(8.69) & $495(1.21)$ \\
\hline $\begin{array}{l}\text { Myrmicaria } \\
\text { opaciventris }\end{array}$ & $282(10.95)$ & $242(9.4)$ & $311(12.08)$ & 197(7.65) & $155(6.02)$ & $185(7.18)$ & $134(5.2)$ & $230(8.93)$ & $94(3.65)$ & $577(22.41)$ & $168(6.52)$ & $\begin{array}{l}2575 \\
(6.32)\end{array}$ \\
\hline $\begin{array}{l}\text { Odontomacus } \\
\text { troglodytes }\end{array}$ & $74(14.6)$ & $38(7.5)$ & $52(10.26)$ & $18(3.55)$ & 17(3.35) & $30(5.92)$ & $94(18.54)$ & $37(7.3)$ & $46(9.07)$ & $97(19.13)$ & $4(0.79)$ & $507(1.24)$ \\
\hline
\end{tabular}




\begin{tabular}{|c|c|c|c|c|c|c|c|c|c|c|c|c|}
\hline \begin{tabular}{|l} 
Pheidole \\
megacephala
\end{tabular} & $301(9.49)$ & $280(8.83)$ & $398(12.55)$ & $155(4.89)$ & $125(3.94)$ & $249(7.85)$ & $222(7)$ & $322(10.15)$ & $309(9.74)$ & $660(20.81)$ & $151(4.76)$ & $3172(7.79)$ \\
\hline \multicolumn{13}{|c|}{ Lepidoptera } \\
\hline $\begin{array}{l}\text { Sphenarches } \\
\text { anisodactylus }\end{array}$ & $0(0)$ & $0(0)$ & $8(0.71)$ & $0(0)$ & $0(0)$ & $\begin{array}{r}2(0.18) \\
\text { thoptera }\end{array}$ & $1(0.09)$ & $0(0)$ & $2(0.18)$ & 1106(98.84) & $0(0)$ & $1119(2.75)$ \\
\hline $\begin{array}{l}\text { Atractomorpha } \\
\text { acutipennis }\end{array}$ & $144(19.65)$ & $50(6.82)$ & $127(17.33)$ & $40(5.46)$ & $51(6.96)$ & $40(5.46)$ & $63(8.59)$ & $32(4.37)$ & $28(3.82)$ & $114(15.55)$ & $44(6)$ & $733(1.80)$ \\
\hline $\begin{array}{l}\text { Oxycatantops } \\
\text { spissus }\end{array}$ & $140(14.18)$ & $92(9.32)$ & $135(13.68)$ & $79(8)$ & $\begin{array}{r}\text { 53(5.37) } \\
\text { Poly }\end{array}$ & $\begin{array}{l}50(5.07) \\
\text { desmida }\end{array}$ & $77(7.8)$ & $60(6.08)$ & $43(4.36)$ & $182(18.44)$ & $76(7.7)$ & $987(2.42)$ \\
\hline $\begin{array}{l}\text { Habrodesmus } \\
\text { falx }\end{array}$ & $79(13.93)$ & $45(7.94)$ & $68(11.99)$ & $36(6.35)$ & $31(5.47)$ & $32(5.64)$ & $20(3.53)$ & $61(10.76)$ & $9(1.59)$ & $99(17.46)$ & $87(15.34)$ & $567(1.39)$ \\
\hline \multicolumn{13}{|c|}{ Spirostreptida } \\
\hline $\begin{array}{l}\text { Trichochalopuncus } \\
\text { sp. }\end{array}$ & $102(19.92)$ & $48(9.38)$ & $92(17.97)$ & $34(6.64)$ & $15(2.93)$ & $23(4.49)$ & $38(7.42)$ & $27(5.27)$ & $10(1.95)$ & $63(12.3)$ & $60(11.72)$ & $512(1.26)$ \\
\hline \multicolumn{13}{|c|}{ Thysanoptera } \\
\hline Thrips sp. & $199(32.46)$ & $88(14.36)$ & $0(0)$ & $120(19.58)$ & $27(4.4)$ & 11(1.79) & $24(3.92)$ & $13(2.12)$ & $28(4.57)$ & $103(16.8)$ & $0(0)$ & $613(1.50)$ \\
\hline Total & $3358(11.22)$ & $1953(6.53)$ & $2564(8.57)$ & $3189(10.66)$ & $1658(5.54)$ & $1799(6.01)$ & $2264(7.57)$ & $2329(7.78)$ & $1461(4.88)$ & $8471(28.31)$ & $878(2.93)$ & $29924(73.45)$ \\
\hline
\end{tabular}

\section{CONCLUSION}

The present study shows that the invertebrate fauna associated with Cucurbitaceous at Minko'o (southern Cameroon) is highly diversified, with a total of 40,741 individuals arranged into 20 orders, 117 families and 412 species. The main organisms collected were from the class Insect represented by orders Hymenoptera, Hemiptera, Coleoptera Orthoptera and Lepidoptera. The most abundant families were Formicidae, Aphididae, Chrysomelidae, Miridae and Aleyrodidae while the most abundant species were Epuraea sp., H. reticulata, L. villosa, L. occidentalis, L. fissicollis, and M. intermedia (Coleoptera); A. gossypii, B. tabaci, Halticus sp., L. australis and Nesidiocoris sp. (Hemiptera); Apidae-Gen.142 sp., A. mellifera, C. flavomarginatus, L. guineensis, M. opaciventris, O. troglodytes and P. megacephala (Hymenoptera), A. acutipennis and O. spissus (Orthoptera) and S. anisodactylus (Lepidoptera). Looking at the high level of biological diversity on cucurbits, the future study may have stated on the specific diversity of entomofauna and their functional statute on the host plant, to clearly define this pest states or importance as biological control of the pest species population. Despite the high number of unidentified species, the present studies provide baseline data for ecological studies, prior to an implementation of a potential integrated pest management strategy.

\section{REFERENCES}

Adégbola, Y. P., Singbo, A. G. (2001). Analyse socio-économique de la filière des biopesticides en cultures maraîchères au Bénin. PAPA/INRAB et IITA-Cotonou, Bénin.

Adja, N. A., Danho, M., Alabi, T. A. F., Gnago, A .J, Zimmer J-Y., Francis, F., Kouassi, K. F., Baudoin, J-P. and Zoro, B. I. E. (2014). Entomofaune associée à la culture de cucurbites oléagineuses africaines (Lagenaria siceraria Molina (Standl. 1930) et Citrullus lanatusThumb (Matsum and Nakai 1916)) et impact des ravageurs sur la production. Annales de la Société entomologique de France (N.S.). 50(3-4) : 301-310.

Assi, A.N.M., Aboua, L.R.N., Ossey, C.L. and Tano, D.K.C., 2018.Entomofauna of cucumber Cucumis sativus (L.), damage assessment caused by insect pests in Dabou in south of Côte d'Ivoire. International Journal of Fauna and Biological Studies 5(6): 2734.

Azo'oEla, M. and Messi, J. (2012).Yield responses of Cucumeropsis mannii (Cucurbitaceae) to the presence or the absence of the insect foraging activity at Nkolbisson in Cameroon. Journal of Animal and Plant Science. 13(3): 1791-1799.

Azo'oEla, M., Tchuenguem Fohouo, F-N. and Messi, J. (2017). Biological diversity of the entomofauna associated with Citrullus lanatus (Cucurbitaceae) flowers and assessment of its impact on yields. Journal of Entomology and Zoology Studies. 5(5): 810-815.

Beucher, O. and Bazin, F. (2012).L'agriculture en Afrique face aux défis du changement climatique: Négociation Climat pour toute l'Afrique Réussie (NECTAR). Baastel/ Iram, QUÉBEC.

Bolton, B. (1994). Identification guide to the ant genus of the world. Cambridge: Harvard University.

Bordat, D. and Arvanitakis. (2004). Catalogues des Arthropodes des cultures légumières d'Afrique de l'Ouest, Centrale, Mayotte et Réunion. CIRAD, Montpellier. France.

Bordat, D. and Goudegnon, E. (1991). Catalogue des principaux ravageurs des cultures. Cambridge, Massachusetts.

Bowombé, T. M. P. (2010). Contribution à la connaissance de l'arthropodofaune de Abelmoschus esculentus (Linné, 1753) Moench (Malvaceae) à Yaoundé. Master en biologie soutenue à l'Université de Yaoundé 1.

Chougourou, D. C., Agbaka, A., Adjakpa, J. B., Koutchika, R. E., Kponhinto, U. G. and Adjalian, E. J. N. (2012). Inventaire préliminaire de l'entomofaune des champs de tomates (Lycopersicon esculentum Mill) dans la Commune de Djakotomey au Bénin. International Journal Biological and Chemical Sciences. 6(4): 1798-1804.

Delvare, G. and Aberlenc, H. P. Les insectes d'Afrique et d'Amérique Tropicale: Clés pour la reconnaissance des familles. PRIFAS/CIRAD.

Djiéto-Lordon, C., Heumou, C. R., Elono Azang, P. S., Ngueng, A. C. and Ngassam, P. (2014). Assessment of pest insects of Capsicum annuиm L. 1753 (Solanaceae) in a cultivation cycle in Yaoundé. International Journal Biological and Chemical Sciences.8 (2): 621-632. 
Dupriez, and De Leener, (1987). Les Cucurbitacées : Jardins et vergers d'Afrique (ed. Harmattan, Terres et Vie), Rue Laurent Delvaux 13, 1400 Nivelles, Belgique. 295-305.

Elono Azang P. S., Aléné, D. C., Heumou, C. R., Ngassam, P. and Djiéto-Lordon, C. (2016).Diversity, abundance and incidence of fruit pest insects on three Solanum varieties (Solanaceae) in two agroecological zones of Southern Cameroon. African Journal of Agricultural Research.11(39): 3788-3798.

Fokou, E. Achu, M. B. and Tchouanguep, M. F. (2004). Preliminary Nutritional Evaluation of Five Species of Egusi Seeds in Cameroon.African Journal of Food, Agriculture, Nutrition and Development (AJFAND). 4(1): 1 -11.

Fomekong, A., Messi, J., Kekeunou, S., Tchuenguem-Fohouo, F-N. and Tamesse, J. L. (2008).Entomofauna of Cucumeropsis mannii Naudin, its impact on plant yield and some aspects of the biology of Dacus bivitatus (Diptera, Tephritidae). African Journal of Agricultural Research. 3(5):363-370.

Heumou, C. R., Djiéto-Lordon, C., Aléné, D. C. and Elono Azang, P. S. (2015).Diversity and agronomic status of tomato and pepper fruit pests in two agro-ecological zones of Southern Cameroon: Western Highland and the Southern Plateau of Cameroon. African Journal of Agricultural Research. 10(11):1224-1232.

Hölldobler, B. and Wilson, E. O. (1990).The Ants. Belknap Press of Harvard University Press, Cambridge.

Jeffrey, (1990).Systematics of the Cucurbitaceae: an overview. In: Bates, D M, Robinson R W and Jeffrey C. eds. Biology and utilization of the Cucurbitaceae. Ithaca, New York: Cornell University Press: 3-9.

Kengue, J., Ebete Mbeng, A., Ntsengue Levodo, J., Assoumou, H. and Fondi, E.N., (2008).Rapport national sur l'état des ressources phylogénétiques pour l'alimentation et l'agriculture : Deuxième rapport sur l'état des ressources phytosanitaires pour l'alimentation et l'agriculture du Cameroun. Ministère de la Recherche Scientifique et de l'Innovation / IRAD.

Kumar R., 1991. La lutte contre les insectes ravageurs : la situation de l'agriculture africaine (régions tropicales). Karthala/CTA, Wageningen.

Lambert, N. (2010). Applicabilité de la lutte biologique aux ravageurs au Québec. Centre Universitaire de Formation en Environnement en vue de l'obtention du grade de maître en environnement. Université de Sherbrooke Québec, Canada.

Letouzey, R. (1985). Notice de la Carte phytogéographique du Cameroun au 1/500 000. V.4. Domaine de la forêt dense humide toujours verte. ICIV., Toulouse. 95-142.

Mestre, J. (1988). Les Acridiens des formations herbeuses d'Afrique de l'Ouest. CIRAD - PRIFAS : Montpellier.

Michel, B. and Bournier, J. P. (1997).Les auxiliaires dans les cultures tropicales. CIRAD, Montpellier-France.

Mokam, D. G., Djiéto-Lordon, C. and Bilong Bilong, C-F. (2014). Patterns of species richness and diversity of insects associated with cucurbit fruits in the southern part of Cameroon. Journal of Insect Sciences. 14(248): 1-9.

Mokam, D. G., Djiéto-Lordon, C., Bilong Bilong C-F. and Lumaret, J-P. (2018). Host Susceptibility and Pest Status of Fruit Flies (Diptera: Tephritidae) Attacking Cucurbits in Two Agroecological Zones of Cameroon, Central Africa. Entomological Society of Southern Africa. 26(2):317-332.

Nguegang, P. A. (2008). L'agriculture urbaine et périurbaine à Yaoundé : analyse multifonctionnelle d'une activité montante en économie de survie. Docteur en Sciences Agronomiques et Ingénierie Biologique, Université Libre de Bruxelles.

Poutouli, W., Silvie, P. and Aberlenc, H. P. (2011). Hétéroptères phytophages et prédateurs d'Afrique de l'Ouest. Edition Quae.

Suchel, J. B. (1988). Les climats du Cameroun V3 domaine des climats subéquatoriaux et équatoriaux. Thèse de Doctorat D’État. Université de Saint-Etienne. France. 795-1188.

Taylor, B. (2010).The ant of sub-Saharan African (Hymenoptera: Formicidae). "http://www.antbase.org/ant/africa". 2010.

Vayssières, J. F., Delvare, G., Maldès, J. M. and Aberlenc, H. P. (2001).Inventaire préliminaire des arthropodes des cultures maraichères sur l'Ile de la Réunion. Insect Science Application. 21(1) 1-22.

Vilardebo, A. (1979). Le charançon du bananier. Cosmopolites sordidus germar. Principes de lutte In : Congrès sur la Lutte contre les Insectes en Milieu Tropical, Marseille, France, 13-19 mars 1979. Montpellier : GERDAT-IRFA, 10 p.

Villiers, A, (1952). Hémiptères de l'Afrique noire. IFAN, Dakar.

Villiers, A. (1948). Faune de l'empire français IX hémiptères réduviidés de l'Afrique noire. Librairie Larose II, Rue Vietor-Cousin (5ème).

Vinutha, B., Kotikal, Y. K., Venkateshalu, Ganiger, V. M., Manjunath, G. and Suvarna P. (2017).Insect-pest composition and natural enemy's association on oriental pickling melon, Cucumis melo var. conomon. Journal of Entomology and Zoology Studies. 5(5): 1838-1848. 